\title{
Social Entrepreneur in Environmentally Friendly Unutilized Land: A Sustainable Effort to Develop Village Economy
}

\author{
Nur Endah Retno Wuryandari Mahdalena Lubis Ryani Dhyan Parashakti \\ Universitas Mercu Buana, DKI Jakarta, Indonesia
}

\begin{abstract}
Social entrepreneurs right now take places in the discussion and gradually become an important element at the global level. Along with population growth in Indonesia, if it is unaccompany by economic growth, various social problems will arise such as unemployment and prolonged poverty. This paper should provide an alternative solution to drive the village economy through a social entrepreneurship approach by empowering human resources, namely instilling the values of independence, is a concrete step and the key to success is to overcome social inequality, strengthen the welfare and capacity of the community. In order for them to be literate in modern agriculture, technology, distribution channels and open a window of insight to the outside world even able to compete. Also empowering the potential of the natural environment. That to develop Indonesia into a large, strong and great country, village contributions have the potential to play an important role. Also, the welfare of rural communities in the sustainable. Many villages still have extensive land that has not cultivated properly. Various obstacles are the cause. The limitations of irrigation facilities, infrastructure, knowledge, and technology are usually obstacles. Finally, it leads to the poverty chain. It drives a social entrepreneur approach to rural unutilized areas and organic systems to provide solutions for different colors. Developing the village economy by changing its social and environmental life, so that there is a change in people's understanding and awareness of their potential, but still friendly to the environment.
\end{abstract}

Keywords: Village Economy, Social Entrepreneur, Village Empowerment, unutilized land, environmentally friendly DOI: $10.7176 / \mathrm{JESD} / 10-8-17$

Publication date: April $30^{\text {th }} 2019$

\section{INTRODUCTION}

We cannot separate the development of Indonesia from its agricultural sector. Agriculture has a large contribution to Indonesia's development and also its economic acceleration. Agriculture contributes as the supply of raw materials, absorbs labor, provides food, capital and also contributes to increasing the country's income and foreign exchange. Therefore, the acceleration of development in the agricultural sector itself is one of the important elements in encouraging economic acceleration in Indonesia 2010-2022 and the welfare of village farmers in particular. (SB IPB in Agrimedia, 2011).

The challenge of developing agriculture itself often occurs because of several things such as high urbanization so that the agricultural sector is in demand and climate change results in crop failure. (Asnamawati, 2015). The potential land with the following data:

Table 1 Estimated of Unutilized Land

\begin{tabular}{|lll|} 
Potential land/ Unutilized land & \multicolumn{1}{c}{$\begin{array}{c}\text { Large } \\
\text { (Acres) }\end{array}$} & Explanation \\
\hline Indonesia & Around 33.4 million & Using 9.3 million hectares for plantations and agriculture \\
\hline Jawa Barat & About 80,000 & 20,000 hectares have 34 of use rights but not well managed. \\
\hline
\end{tabular}

Source: Tribunnews, 2018

From Table 1.1 above shows that the potential for empowerment by managing unutilized land still provides flexibility to work on. They expect effective and efficient management by involving stakeholders, namely local government to be a good collaborator.

In the countryside, most farmers have land of only 0.5 hectares and even farmers do not have land at all. They believe its food production in West Java will increase if they can manage if the potential land for the cultivation of agricultural commodities. (Jabartoday, 2013)

In addition, the priority aspect of agricultural development itself is infrastructure. But unfortunately, agricultural infrastructure is inadequate in supporting increased agricultural yields, both in terms of quantity, conditions and the spread of availability. There are still many rural areas that have not touched by the construction of agricultural infrastructure, causing agriculture in Indonesia to be lagging. (IPB Journal in Agrimedia, 2011). Likewise, the quality of human resources (farmers) is still limited. The ability and enthusiasm of the farmer in moving the village through entrepreneurship are relatively weak, making it difficult to get a decent income, and this is one of the socio-economic factors that hinder their potential in managing productive micro-businesses in the countryside. (Dumasari. 2014: 196).

The village-based social entrepreneur is one answer and concrete steps important in helping to move the rural economy to ease social problems, especially poverty. (Firdaus. 2014: 65) Village role or participation needed by instilling social values as a basis for entrepreneurship (Hulgard. 2010 in Utomo 2014: 6) in the form of a spirit of independence, togetherness, and concern to solve problems together to produce creative rural communities, 
innovative (Hasanah, 2015: 269) and open a window of insight to the outside world to compete without having to urbanize. Through village-based social entrepreneurs, farmers can know the reality that is happening around them who can then carry out concrete actions in the form of economic movements in the village.

Caringin Village is at an altitude of $600-1200 \mathrm{M}$ above sea level is one village in the District of Gegerbitung between 106 - 450 BT in 70 South Latitude. Caringin Village is in charge of 21 sub-villages or villages, while they leave behind most, such as Benjot Sub-village. The agricultural causes of the area are lagging because the agricultural system depends on the natural situation, the geographical location of the land is many hills and there is no irrigation system, as a result, many lands becomes ineffective or called unutilized land. The role of village youth in driving the village economy is still weak because of the lack of modern knowledge of agriculture that is more efficient and about the entrepreneurial spirit. In addition, they do not know the lack of capital in managing land and distribution lines of agricultural products to the public so that middlemen become rampant. The performance is not much different from agriculture, if entering the dry season, farmers look for grass to other villages that are far away. To fulfill the daily needs of the local people is difficult, and this has been going on for a long time.

\section{Problem Identification}

From the results of field observations and implementation, we collect the partner problem in Benjot Sub-village, including the following;

1. Difficulty in irritation, small rivers become the foundation of residents and the distance is far from agriculture in the hills.

2. Management of agriculture based on hereditary knowledge, regardless of the challenges that have changed. The role of youth is still minimal to build the village economy with the potential they have.

3. The difficulty of goat feeding is in the dry season for almost every citizen.

4. Limitations on capital management so they ensnare the debt.

5. The high rate of dropout and early marriage because of limited costs.

From the problems above, the handling of the basic problems of the Benjot Sub-village community must be done immediately to overcome the existing problems while preventing the potential for greater problems to arise. Given these problems have been going on for a long time and continue to the next generation. We need a program that can change systemically including understanding and behavior of its citizens.

\section{Social Entrepreneur for Sustainable Village Community Empowerment}

Ropke (2004), Rahmawati (2009) in Dumasari (2014: 197) states that a person or group of people including farmers can carry out the process of creating new conditions creatively and productively where the results differ from the old ones, thus potentially increasing the added value. Entrepreneurship has three routine functions, namely the application of management principles through the use of resources owned.

The function of arbitration is to take risks by using opportunities and innovative functions to buy a variety of innovations for business development that managed. Thus, entrepreneurship is a productive, creative and innovative behavior that belongs to a person, including a farmer, or is a real reflection of one's attitude, cognitive and psychomotor in taking advantage of various opportunities and opportunities to get something that is economically useful for themselves and their environment.

The above definition provides an explanation of how entrepreneurs advance systemic change in the social entrepreneurship environment is not independent, the role of farmers in advancing their village economy is very important and needs to empower. In principle, every farmer has the potential to develop entrepreneurial skills and enthusiasm to build his village (awareness, willingness, and competence) with internal parties (government, traders, families, consumers, investors, business partners, community leaders, social and other environments) (Dumasari, 2014: 198). This statement supported by Meridith (2005) in Dumasari (2014: 198) explaining that positive attitudes, experience, determination, hard work, and perseverance are valuable determinants and prerequisites in maintaining soul, developing, and entrepreneurial abilities.

Efforts to improve the dignity and status of the people are in poor condition so they can release themselves from the trap of poverty and backwardness by encouraging, motivating, building community capacity and summarizing the value of social values is the meaning of community empowerment. An economic development concept that summarizes the value of social values. This reflects the new paradigm of human-centered development, participation, empowerment, and sustainability.

The concept of empowerment is broader than just meeting basic needs or just a mechanism to prevent further poverty processes. How entrepreneurs do in various ways, by encouraging, motivating, building community capacity, summarizes the value of social values. (Zubaedi, 2013 in Afrianto and Balamar, 2014: 56-57). Adi (2013) in Afrianto and Balamar, 2014: 56-57, explained that sustainable empowerment as a cycle comprises five main stages, namely:

1. Bring back empowering and non-empowering practices 
2. Discuss the reasons for empowerment and helplessness

3. Identify a meaningful power base to make changes.

4. Develop action plans and implement them.

In line with the Minister of Home Affairs Republic of Indonesia Number 7 of 2007, Article 1, paragraph (8) concerning Community Empowerment Cadres, states that community empowerment is a strategy used in community development as an effort to realize capabilities and independence in the community, national and state life. The core of the notion of community empowerment is a strategy to realize the ability and independence of the community. Minister of Home Affairs Regulation Number 66 of 2007, concerning Village Development Planning, Article 5 paragraph (2) empowerment is an effort to realize the ability and independence of the community in the community's life, nation and state.

One of the social entrepreneurship activities is to activate unutilized land caused by natural factors such as geographical location, inadequate infrastructure, and others. Setyawan et al. (2016: 2), Unutilized land is an abandoned agricultural area, with no utilization of productive agricultural activities on the land. For example, land conditions that overgrown with non-productive plants are less useful, such as shrubs, because these lands were once forests that cleared for agriculture only taken in large quantities and not used.The farmer can reuse used agricultural land as agricultural land if farmers understand the way to manage the land, with extension help from the government and non-governmental organizations, it is possible to achieve this. Most idle land is the most suitable dry land for farming. Albert Guttenberg (1959) in Setyawan etc. (2016: 2), land use is a key term in the language of urban planning. Jurisdictional politics will carry out land use planning and regulate land used to avoid land use conflicts. It implements land use plans through land divisions and procedures for use and regulation, such as zoning regulations.

From observing the problems in the field, we proposed several alternative solutions based on existing resources. The researchers conduct the calculations immediately. Mapped in Table 2 below:

\section{Table 2 Partner Problems and Proposed Solutions}

\begin{tabular}{|c|c|c|}
\hline NO & Problems & Solution \\
\hline 1 & $\begin{array}{l}\text { The geographical location of agriculture } \\
\text { is hilly so the waters are very difficult } \\
\text { because there is no irrigation. The small } \\
\text { river becomes the foundation of the } \\
\text { residents and the distance is far from the } \\
\text { farm in the hills } \\
\text { A lot of lands is unutilized or ineffective } \\
\text { because of infrastructure problems. }\end{array}$ & $\begin{array}{l}\text { Farmers need cooperation with related parties. } \\
\text { a. Provision of infrastructure such as rain shelters for } \\
\text { stocks in summer, for example, tanks or tanks or } \\
\text { making other irrigation systems } \\
\text { b. Farmers would likely to distribute the provision of } \\
\text { water drawers to water reservoirs }\end{array}$ \\
\hline 2 & $\begin{array}{l}\text { Limited knowledge of modern agriculture } \\
\text { and information dissemination } \\
\text { increasingly limits the fulfillment of the } \\
\text { need for the development of knowledge } \\
\text { and knowledge. } \\
\text { The role of youth in entrepreneurship is } \\
\text { still minimal. }\end{array}$ & $\begin{array}{l}\text { a. Socialization, persuasion, and workshops changed the } \\
\text { conventional mindset of agriculture to be modern with } \\
\text { more efficient organic principles. } \\
\text { b. Social entrepreneurship socialization. Benefits and } \\
\text { good values. } \\
\text { c. Giving birth to independent business actors by } \\
\text { involving village youth }\end{array}$ \\
\hline 3 & $\begin{array}{l}\text { Most villagers also raise goats. Limited } \\
\text { feed when summer causes difficulties in } \\
\text { finding grass, therefore they must leave } \\
\text { the village and require additional costs }\end{array}$ & $\begin{array}{l}\text { a. Cooperate with partners experienced in making dry } \\
\text { food concentrates } \\
\text { b. Provision of abundant grass processing equipment in } \\
\text { the rainy season for summer stock (Tools for cutting } \\
\text { grass materials and drying for concentrates) }\end{array}$ \\
\hline 4 & $\begin{array}{l}\text { Limited capital in meeting farmers' needs } \\
\text { is the most important indicator. They need } \\
\text { solutions that can bridge and motivate } \\
\text { interest, curiosity, creativity, etc. } \\
\text { especially for farmers, adolescents as the } \\
\text { generation that will continue the } \\
\text { development of sub-villages. }\end{array}$ & $\begin{array}{l}\text { With the principle of organic able to reduce capital farming } \\
\text { in a way: } \\
\text { a. Using plants around agriculture such as grass, wild } \\
\text { plants, vegetables that are rotten or not suitable to } \\
\text { compost } \\
\text { b. Using waste products such as coconut water, rice } \\
\text { washing, young bamboo, banana humps for organic } \\
\text { fertilizer }\end{array}$ \\
\hline
\end{tabular}




\begin{tabular}{|c|c|c|}
\hline NO & Problems & Solution \\
\hline 5 & $\begin{array}{l}\text { It is necessary to establish a } \\
\text { communication system to the village- } \\
\text { owned enterprises as a subsidy channel } \\
\text { for farmers to stimulate the interest of } \\
\text { village builders and later curiosity that } \\
\text { will start creativity, motivation to move } \\
\text { forward and be creative, but without } \\
\text { substantial costs and no need to leave the } \\
\text { sub-village. }\end{array}$ & $\begin{array}{l}\text { a. Facilitating farmers and village-owned enterprises to } \\
\text { establish harmonious communication } \\
\text { b. Dissemination of village-owned enterprises } \\
\text { c. Involve the community in the activities of the village- } \\
\text { owned business entity program } \\
\text { d. Social entrepreneur socialization to village-owned } \\
\text { enterprises }\end{array}$ \\
\hline 6 & $\begin{array}{l}\text { Supporting problems: } \\
\text { They found it that dropout rates, early } \\
\text { marriage are high for limited costs. }\end{array}$ & $\begin{array}{l}\text { a. Dissemination of the importance of education and } \\
\text { about harmonious marriage. } \\
\text { b. Improvements in farming and livestock systems will } \\
\text { help reduce dropouts and early marriage. }\end{array}$ \\
\hline
\end{tabular}

Source: Authors' survey and various sources

We can bridge village empowerment based on social entrepreneurs as a driver of the rural economy, compared to the level of complexity of existing problems through several concrete steps, starting with socialization to open farmers' insight into the efficient modern agriculture by using natural resources. Engaging farmers in social entrepreneurs to create independent entrepreneurs. We should realize the fulfillment of infrastructure facilities, Collaboration with related parties such as village officials, village-owned business entity and outside parties (Detik Finance, 2018). So it is increasingly clear, village empowerment is the key to success driving economic development to improve people's welfare, that to develop Indonesia into a big, strong and great country, it must start from the village.

\section{Sustainable Social Entrepreneurs}

They have realized social entrepreneurship to have a social impact, especially in easing sustainable poverty. Innovation and ideas outside the limits of general thinking are the main instruments. In addition, creative new ideas in social entrepreneurship often cross traditional boundaries in conventional economic activities. In economic activities that apply conventionally or in social entrepreneurship, printing or giving birth to the entrepreneurship itself to be independent and ready to compete is important. The role of human resources in local village youth is the main target for making better economic changes in his village.

Benjot Sub-village - Caringin Village - Geger Bitung Subdistrict - Sukabumi Regency has gradually changed the agricultural system from conventional to semi-organic farming and finally towards an organic concept to produce efficiency. Plants that tested and succeeded are pepper, vanilla, cucumber, long beans, beans, and chili. This creative innovation and idea was pioneered by Mr. Purwantono as a farmer in Benjot Sub-village and also as chairman of organic fertilizer processing in the Indonesian Vanilla Farmers Association organization. This shows that the local community is open to change and is ready to compete with agricultural prices which will have a high selling value. As Drucker, (1985) stated in Firdaus (2014, p. 61), that the concept of entrepreneurship is creative which encourages innovation and becomes the main tool in exploiting the opportunities available. Entrepreneurship will always seek change and respond and use it as an opportunity to create value and solve problems.

Youth participation is important in building villages, initially, village youths in farming only followed the traditions and patterns of previous people from generation to generation using chemicals ranging from fertilizers to pest control. As a result, large business capital but sales results are not as expected. After getting socialization, workshops and involving farmers in organic farming in stages, and seeing the success of the plantations that became the experiment, the change in mindset and real action of some farmers happened slowly. This means that to change the mindset of village youth to become independent in their efforts and advance their villages, it needs repeated repetition to embed in their minds and in the form of real action to become a model. The same thing was conveyed by Pambudi, (2010) in Widiastuti \& Margaretha, (2011: 5). Even though social entrepreneurship is important for Indonesia, the most urgent thing is to create entrepreneurship itself, not necessarily a pure social entrepreneur. Anyone can establish in becoming a businessman.

Refusal to change because the first conventional agriculture according to them is more effective because all the ingredients of fertilizers and insecticides are available in the store and ready to use and also the calculation of harvest time. It differs from organic where fertilizer must process into compost and liquid fertilizer. Animal manure must brew before they use it, they can even use it for biogas if the infrastructure supports it. This means that organic farming needs fertilizer preparation well before planting. More precisely, village youth do not yet know the information and benefits of organic plants more efficiently in business capital by using natural resources around agriculture such as grass, wild plants, banana weeds, animal feces and others as basic fertilizers. Everett M Roger, (1983) in Mulyadi et al. (2007, p. 111) and Asnamawati (2015, p. 3-4). 
Innovation explains how new ideas and ideas communicate with a culture of culture. The focus of innovation is how a new idea or idea can and may adopt by a particular social group or culture.

Cooperation, diligence, honesty, friendliness, togetherness, please help and also make up a strong social and cultural value in Benjot Sub-village. It shows good values that give birth to trust. Delgado (2004) in Suyatna \& Nurhasanah, (2017, p. 534). Value creation is the first step in building trust. This support by Geertz (2010) and Rianse et al. (2013) in Hasanah (2015: 271), the creative economy based on culture emphasizes culture as a collection of creative ideas and processes from inherited reason then coloring the life of a society. The creative process of reason if implemented in a business field will produce a creative product. Culture is a comprehensive lifestyle, complex, abstract, and broadly polarized in a distinctive image so every product of a creative culturebased industry will have unique characteristics different from others.

The unsolved challenge in agriculture in Benjot sub-village was the first problem of irrigation, the village youth became unproductive when entering the summer, most of whom were not farming, as a result, they were looking for odd jobs. This shows that agricultural infrastructure is still one cause of agricultural backwardness in Benjot Sub-village in particular and in Indonesia where many rural areas are still untouched by agricultural infrastructure development. According to Law No. 7 of 2004 concerning Natural Resources and Government Regulation No.20 of 2006 concerning Irrigation mandates that the responsibility for the management of tertiary irrigation networks to the level of farming (Jitut and Jides become the thing and responsibility of farmers to use water (P3A) according to their capabilities. (www.jurnal.sb.ipb.ac.id p.17)

Second, the problem of drying rice crops during the rainy season, farmers find it difficult to drain, as a result, rice becomes moldy or moist so the rice becomes ugly and has a low selling value. Plantations do not standalone, require an infrastructure system that supports it so it does not depend on the weather. Supporting infrastructure systems according to Grigg, 1988 in Posumah 2015, p. 5, Infrastructure supports the main functions of the economic system in people's lives, such as facilities, equipment, installations, which are the need and built for the functioning of the community's economic system.

The third planting pattern follows market prices and distribution channels for the sale of agricultural products to cut rampant middlemen's paths. For example, if the price of cucumber is high, farmers prefer to plant a crowded cucumber, even though the waiting time for cucumber harvest is 25 days when the harvest arrives, the yield is abundant and the price drops. Access to agriculture hamper by damaged roads, and it used the distance of large markets far from the village to play with prices. This is a challenge in both conventional and organic agriculture. According to Asep Taryana, DPR RI expert in the availability's the matter of infrastructure in sufficient quantities and adequate conditions, it would be easier for farmers to get maximum results from their farming, starting from the cultivation process, access to facilities. production to agricultural products.

Fourth, the coordination and cooperation between the youth of Caringin Village and Village-Owned Enterprises (BUMDes) have not harmonized. Most of the people do not know the role or function of village-owned business entity whereas it also does not use the assets or potential they have to build in the related villages. Based on Law No. 6 of 2014, namely article 87, 88, 89 and 90 mentions BUMDes are business entities whose entire or most capital own by the village through direct participation originating from separated village assets to manage assets, services, and other businesses to the maximum extent possible. The welfare of the village community. www.berdesa.com.

This shows that communication or socialization of village-owned business entity it still constrains to village communities. The less communication related to information for the progress of agriculture in the village, the slower the village develops. But the better communication counseling, the lower the communication barriers to getting information. (Bulkis, 2018, pp. 33-35)

We expect the hopes of the farmers, with organic agriculture to have a high selling value and be able to improve the economy of Benjot Sub-village in particular and the Caringin Village extensively through villagebased social entrepreneurship.

\section{Environmentally Friendly Social Entrepreneurs}

The urgent need for a decent life can encourage people to use ways that even unwittingly damage the environment in which they depend. Using fertilizers and chemicals without properly understanding the use and management will only build its own trap because it triggers damage to the environment and human health. Besides debt bondage to middlemen, it will be more difficult for generations. This happens because of many things, among others, understanding environmental management and the use of chemical mixtures that are not cheap.

Nature has provided an antidote to the problems of agriculture and livestock, which is cheaper, easier, safer because it is environmentally friendly. Plantation management through an environmentally friendly approach to soil fertility, pest and disease control, and plant fertilization. By assisting and socializing the composition and timing of proper fertilization, farmers will increasingly understand the superiority of the environmentally friendly Social Entrepreneur system.

A key aspect of our plantation strategy is also working with related parties. Both fellow farmers and related parties. Given that changing behavior and cropping patterns for farmers is difficult. Help carried out includes the formation of cooperatives/communities, building togetherness among farmers, socialization of agricultural 
knowledge, recommending environmentally friendly fertilizers and even making them, including providing seedlings and financing such as infrastructure improvements.

\section{CONCLUSION}

The basic problem of the Benjot sub-village community is the low income of the community because of the low number and productivity of resources. It must address this and preventing the potential for greater problems to arise. Given these problems have been going on for a long time and continue to the next generation. A program that can change systemically need including understanding and behavior of community members as an effort to empower rural communities.

The management of plantations here programmed through an environmentally friendly approach to soil fertility, pest and disease control, and plant fertilization. By assisting and socializing the composition and timing of proper fertilization, farmers will increasingly understand the superiority of the environmentally friendly Social Entrepreneur system

\section{Acknowledgment}

We would like to thank the parties who have made this Community Service activity possible: Field of Management and PPM of Mercu Buana University which has provided funding and support. Mr. and Mrs. Tono who have shared knowledge and facilities while at the service location, residents of Benjot Sub-village are friendly and cooperative, and all parties we cannot mention.

\section{REFERENCES}

Adi, Isbandi Rukminto. (2013). Intervensi Komunitas \& Pengembangan Masyarakat Sebagai Upaya Pemberdayaan Masyarakat. Jakarta. Rajawali Pers

Asnamawati, Lina. (2015). Strategi Percepatan Adopsi dan Difusi Inovasi Dalam Pemanfaatan Mesin Tanam Padi Indojarwo Transplanter di Kabupaten Bengkulu Utara Provinsi Bengkulu. Jurnal Komunikasi. Universitas Terbuka-UPBJJ Bengkulu.

Bulkis. (2018). Hambatan Komunikasi Yang Dirasakan Petani Selama Pembinaan Petani Padi ( Oriza Sativa ) di Desa Oesako Kabupaten Kupang. Jurnal Matematika, Sains dan Teknologi, Vol. 19. No. 1. Universitas Terbuka

Delgado, Melvin.(2004). Social Youth Entrepreneurship. USA: Greenwood

Dumasari. (2014). Kewirausahaan Petani Dalam Pengelolaan Bisnnis Mikro di Pedesaan. Jurnal Inovasi dan Kewirausahaan. Vo.1. 3, No. 3. Fakultas Pertanian Universitas Muhammadiyah Purwokerto

El, Hasanah Lak Lak Nazhat. (2015). Pengembangan Wirausaha Muda Ekonomi Kreatif Berbasis Budaya di Daerah Istimewa Yogyakarta. Jurnal Studi Pemuda. Vol. 4, No.2. Fakultas Ekonomi Universitas Islam Indonesia

Hardi, Utomo. (2014). Menumbuhkan Minat Kewirausahaan Sosial. Jurnal Ekonomi. STIE AMA Salatiga.

Mulyadi (2007). Proses Adopsi Inovasi Pertanian Suku Pedalaman Arfak di Kabupaten Manokawi -Papua Barat. Jurnal Penyuluhan, Hal...Vol.3, No.2, September 2007. ISSN 1858-2664. Institute Pertanian Bogor.

Meridith. Geoffrey Grant. Robert E., Nelson and Philip A., Nect. (2005). The Practice of Entrepreneurship. International Labor Office. Geneva.

Nur, Firdaus., (2014). Pengentasan Kemiskinan Melalui Pendekatan Kewirausahaan Sosial. Jurnal Ekonomi dan Pembangunan. Vol. 22, No. 1. Peneliti Pusat Penelitian Ekonomi Lembaga Ilmu Pengetahuan Indonesia.

Posumah, Ferdi. (2015) Pengaruh Pembangunan Infrastruktur Terhadap Investasi di Kabupaten Minahasa Tenggara, Hal.5. Jurnal Ilmiah Efisiensi. Vol.15, No.2, Tahun 2015. Fakultas Ekonomi dan Bisnis Universitas Sam Ratulangi Manado.

Rogers, Everett. (1983). Diffusion of Innovations, Third Edition. New York: The Free Press

Rogers. Everett. (2003). Diffusion of Innovations. 5th ed. New York: Free Press

Setyawan, Dicky., Sulistyowati, Astuti, Puji., (2016). Pemberdayaan Petani dengan Pemanfaatan Lahan Tidur Untuk Pertanian BioFarmaka di Kecamatan Dawe Kabupaten Kudus. Journal Ilmu Pemerintahan, Vol. 5, No. 1. Universitas Diponegoro.

Suyatna, Hempri dan Nurhasanah, Yanti. (2017) Sociopreneurship Sebagai Tren Karir Anak Muda. Jurnal Studi Pemuda, Vol.6, No.1, Mei 2017. Universitas Gajah Mada

Widiastuti, Ratnda dan Margaretha, Melly. (2011) Socio Entrerpreneurship : Tinjauan Teori dan Perannya Bagi Masyarakat. Jurnal Manajemen, Vol. 11, No. 1. ISSN 1441-9293. Universitas Kristen Maranatha

Widiastuti, Ratnda dan Margaretha, Melly. (2011) Socio Entrerpreneurship : Tinjauan Teori dan Perannya Bagi Masyarakat. Jurnal Manajemen. Vol.11, No.1, November 2011. ISSN 1411-9293. Universitas Kristen Maranatha, Zubaedi. (2013). Pengembangan Masyarakat. Jakarta: Kencana Prenada Media Group www.berdesa.com. Diakses tanggal 25 November 2018 : 06.10 WIB

www.jurnal.sb.ipb.ac.id/index.php/agrimedia/article/download/30/30. 2011. Retrieved 25 November 2018 : 06.00 WIB https://finance.detik.com/berita-ekonomi-bisnis/d-2273417/30-juta-hektas-lahan-potensial-di-indonesia-menganggur. Retrieved 28 November pukul 07.14

https://www.kompasiana.com/123154_adji/54f36d947455137a2b6c750a/pertanian-indonesia-potensi-besar-tetapi- 
belum-dioptimalkan. Retrieved 28 November 2018 at 07.30

https://nasional.kompas.com/read/2008/04/23/13364840/80.000.hektar.lahan.tidur.di.jabar. Retrieved 28 November at 08.00

https://www.jpnn.com/news/indonesia-punya-potensi-lahan-tidur-seluas-93-juta-hektare?page=1. Retrieved November 2018 at 05.00 WIB

http://www.tribunnews.com/regional/2018/04/12/kementan-dorong-optimalisasi-lahan-tidur-di-daerah-daerah. Retrieved 28 November 2018 at 07.00 WIB

https://finance.detik.com/berita-ekonomi-bisnis/d-4259491/bumdes-diharapkan-jadi-kunci-pergerakan-ekonomi-desa. Retrieved 29 November 2018 at 08.00 WIB 